\title{
ROCK GLACIER MONITORING USING AERIAL PHOTOGRAPHS: CONVENTIONAL VS. UAV-BASED MAPPING - A COMPARATIVE STUDY
}

\author{
V. Kaufmann ${ }^{1, *}$, G. Seier ${ }^{2}$, W. Sulzer ${ }^{2}$, M. Wecht ${ }^{2}$, Q. Liu $^{3}$, G. Lauk ${ }^{3}$, M. Maurer ${ }^{4}$ \\ ${ }^{1}$ Institute of Geodesy, Graz University of Technology, Steyrergasse 30, 8010 Graz, Austria - \\ viktor.kaufmann@tugraz.at \\ ${ }^{2}$ Department of Geography and Regional Science, University of Graz, Heinrichstraße 36, 8010 Graz, Austria - \\ (gernot.seier, wolfgang.sulzer, matthias.wecht)@uni-graz.at \\ ${ }^{3}$ Institute of Applied Geosciences, Graz University of Technology, Steyrergasse 30, 8010 Graz, Austria - \\ (qian.liu,gerhard.lauk)@tugraz.at \\ ${ }^{4}$ Institute of Computer Graphics and Vision, Graz University of Technology, Inffeldgasse 16/II, 8010 Graz, Austria - \\ maurer@tugraz.at
}

\section{Commission I, ICWG I/II}

KEY WORDS: Rock glacier, Mountain permafrost, Photogrammetry, Monitoring, Change detection, UAV, SfM, Tschadinhorn

\begin{abstract}
:
Rock glaciers are creep phenomena of mountain permafrost. Typically, these landforms look like lava flows from a bird's eye view. Active rock glaciers move downslope with flow velocities in the range of few centimeters to several meters per year. Thus, large masses of rock and ice can be gradually transported down-valley. In this paper we present a comparative study analyzing surface change for Tschadinhorn rock glacier, a relatively fast moving rock glacier located in the Hohe Tauern Range of the Austrian Alps. Aerial photographs (1954-2017) of both metric (conventional) and non-metric (UAV-based) aerial surveys were compared to derive multi-annual to annual flow vector fields and surface height change. For each time interval given we computed a single representative value for flow velocity and, if applicable, also for area-wide surface height change, i.e. volume change. The velocity graph obtained represents the temporal evolution of the kinematics of the rock glacier with good discrimination. Volume change was difficult to quantify since temporal changes were rather small and close to insignificance. The precision and accuracy of the results obtained were numerically quantified. Our study showed that for the Tschadinhorn rock glacier UAV-based aerial surveys can substitute conventional aerial surveys as carried out by national mapping agencies, such as the Austrian Federal Office of Metrology and Surveying (BEV). Thus, UAV-based aerial surveys can help to bridge the data gap between regular aerial surveys. The high accuracy of the UAV-derived results would even allow intra-annual change detection of flow velocity.
\end{abstract}

\section{INTRODUCTION}

\subsection{Rock glacier monitoring}

Rock glaciers are creep phenomena of mountain permafrost and can be found in all high mountain areas of the Earth (Barsch, 1996). Rock glaciers are composed of rock debris and ice and are common geomorphological landforms of the periglacial environment. They must not be confused with glaciers or debris-covered glaciers. Rock glaciers move downslope by force of gravity as a result of the plastic deformation of their interstitial ice and other internal processes, such as sliding along distinct shear horizons. They thus become deformed over time, acting as prominent mass transport systems in alpine environments. From a bird's eye view rock glaciers resemble tongue or lobate shaped lava flows.

Flow/creep velocities of rock glaciers are in the order of a few centimeters to several meters per year and movement rates may change from year to year. Moreover, the flow velocity is also subject to seasonal changes. It is believed that medium to longterm acceleration/deceleration of rock glacier movement is caused by climate change, i.e. atmospheric warming/cooling.
Surface height change of a rock glacier is not only a direct result of the glacier's kinematics but also of ice melt/aggregation due to the prevailing climate conditions and rock weathering at the head walls. In general, obvious ice melt due to atmospheric warming is rather low, as opposed to normal glaciers, and has been estimated to be in the centimeter range. In fact, a clear answer can only be given by a thorough surface mass balance analysis as used in glaciology, which includes all kinds of mass flow to/from the catchment area where the rock glacier is located.

\subsection{Motivation}

In this paper we use aerial photographs taken from both manned aircraft (conventional aerial surveys) and unmanned aerial vehicles (UAVs) in order to retrieve multi-annual to annual kinematic data of the fast moving Tschadinhorn rock glacier (see description next section). Both historical and more recent aerial photographs (10 epochs between 1954 and 2015) were acquired from the Austrian Federal Office of Metrology and Surveying (BEV). BEV intends to repeatedly take aerial photographs of the whole territory of Austria every 3 years from 2010 onwards. In 2016 and 2017 in-house UAV overflights were carried out to fill the time gap until the next

\footnotetext{
* Corresponding author
} 
scheduled BEV survey. All of these data were processed to provide the basis of the intended monitoring of Tschadinhorn rock glacier using both multi-temporal high resolution digital orthophotos (DOPs) and digital terrain models (DTMs). Change in surface movement and surface height is determined by comparing these base data.

\section{STUDY AREA}

Tschadinhorn rock glacier $\left(46^{\circ} 59^{\prime} 38^{\prime \prime} \mathrm{N}, 12^{\circ} 51^{\prime} 47^{\prime \prime} \mathrm{E}\right)$ is a fastmoving rock glacier located in the Schober Mountains, Hohe Tauern Range, East Tyrol, Austria. The study area is part of the core zone of the Hohe Tauern National Park (Figure 1). The tongue-shaped rock glacier is approx. $640 \mathrm{~m}$ long and 80 to 100 $\mathrm{m}$ wide and covers an area of approx. 5.35 hectares. It stretches between $2835 \mathrm{~m}$ a.s.l. (upper limit of the root zone) and $2568 \mathrm{~m}$ (lower end of the tongue). Its surface topography is characterized by typical flow structures, such as furrows and ridges, levees and tension cracks (Figure 2). The study actually comprises two rock glaciers, i.e., Tschadinhorn rock glacier (no. is186) and another rock glacier (no. is 185) which is located to the northeast. Furthermore, talus slopes exist to the south of the rock glacier (elevation range between 2675 and $2800 \mathrm{~m}$ ), which show signs of surface deformation indicating active downward movement.

Tschadinhorn rock glacier is moving over a break in slope from a low inclined root zone into steeper terrain. The rock masses move downslope following the talweg. The snout of the rock glacier acts like a bulldozer breaking the ground/sod at the frontal end. At the orographic right side loose rock masses are pushed over a terrain ridge and fall to lower elevations of the adjacent slope (Figure 3). In the steep slope area the previously mentioned tension cracks have already developed. Surficial rocks are often loose and thus hamper walking on the rock glacier. The surface morphology mentioned above is typical of a highly active rock glacier.

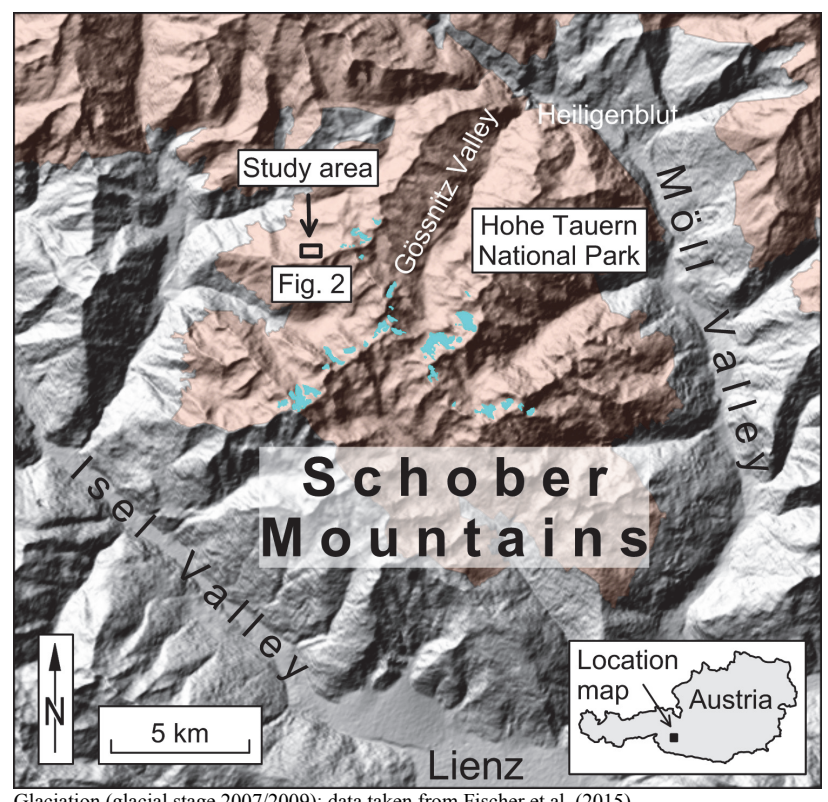

Glaciation (glacial stage 2007/2009): data taken from Fischer et al. (2015) Data source of digital terrain model: Land Tirol - data.tirol.gv.at

Figure 1. Location map

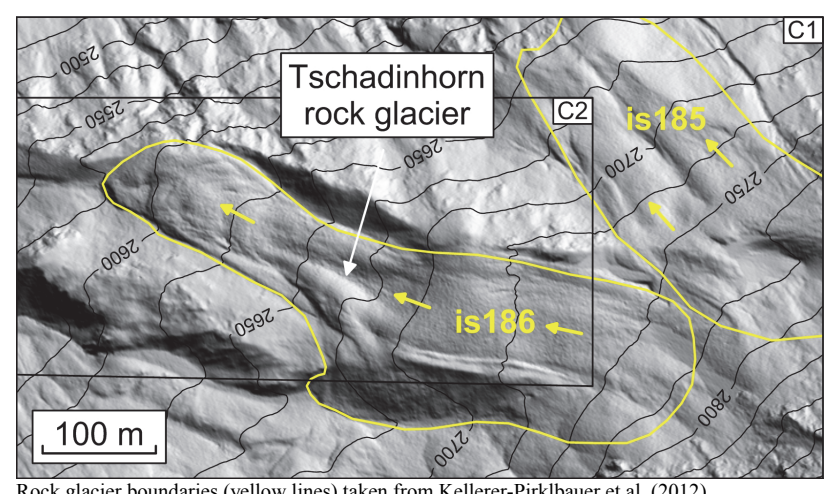

Data source of ALS-based digital terrain model: Land Tirol - data.tirol.gv.at

Figure 2. Shaded relief of the study area

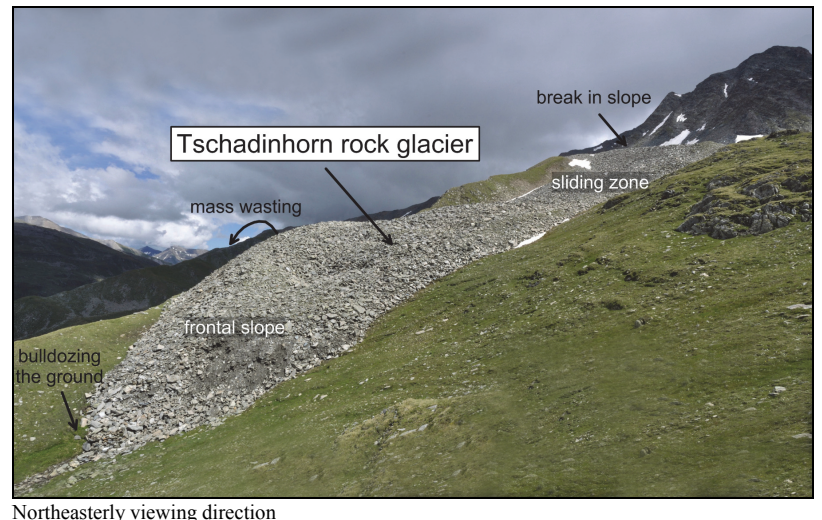

Figure 3. Panoramic photo taken on 1.8.2014

\section{PREVIOUS WORK}

First permafrost studies were carried out in the study area by Buchenauer (1990). Based on field observations such as temperature of springs $\left(0.4-0.8^{\circ} \mathrm{C}\right)$, steep frontal slopes without vegetation, evidence of near subsurface water flow and unstable surficial rocks, the author assumed that both rock glaciers of the study area are under permafrost conditions and evidently active. Additionally, Buchenauer carried out two refraction seismic profile measurements at Tschadinhorn rock glacier which also evidenced permafrost. Buchenauer also recognized a layered structure of units of different age and kinematic state, i.e., active and inactive, for Tschadinhorn rock glacier. Buchenauer also provided a precise description of its flow mechanism for the first time.

First measurements of the flow velocity were carried out by Kaufmann (2010, 2012), who used multi-temporal backdrop images of virtual globes, Google Maps and Microsoft Bing Maps, to quantify surface change, i.e. horizontal movement. He measured a maximum flow velocity of $1.24 \pm 0.09 \mathrm{~m} /$ year for the time period 2002-2006. In a follow-on study Kaufmann \& Kellerer-Pirklbauer (2015) acquired multi-temporal orthophotos (2002, 2009, and 2012) from governmental agencies (Tyrol and Carinthia) and repeated the previous study obtaining more accurate results. Finally, the highest accuracies were obtained in the change detection analysis using the original photographs in a standard photogrammetric workflow (Filwarny and Wisiol, 2012; Mikl, 2015; Kaufmann, 2017). This workflow also allowed surface height change of the rock glacier to be quantified. 


\section{DATA}

In this study we used (1) metric photographs of conventional aerial surveys, (2) non-metric photographs of UAV-based aerial surveys, (3) airborne laser scanning (ALS) data, and (4) geodetic measurements.

\subsection{Metric aerial photographs 1954-2015}

Historical and also more recent aerial photographs (in total 10 epochs between 1954 and 2015, see Table 1) were acquired from the Austrian Federal Office of Metrology and Surveying (BEV), which holds a large archive of aerial photographs of conventional aerial surveys dating back to the early 1950s. All image data were provided in digital format. Camera calibration protocols of all cameras used and elements of exterior orientation of selected epochs (2002, 2012 2015) were also provided.

\begin{tabular}{|c|c|c|c|}
\hline Date & $\Delta \mathrm{H}_{\mathrm{g}}{ }^{1}(\mathrm{~m})$ & Camera & Scale $/ \mathrm{GSD}^{4}(\mathrm{~cm})$ \\
\hline 24.9 .1954 & 3250 & $A^{2}(b \& w)$ & $1: 15,450 / 23$ \\
\hline 29.9 .1969 & 4345 & $\mathrm{~A}(\mathrm{~b} \& w)$ & $1: 28,460 / 43$ \\
\hline 6.9 .1974 & 2080 & $\mathrm{~A}(\mathrm{~b} \& \mathrm{w})$ & $1: 12,830 / 12$ \\
\hline 9.10 .1981 & 4660 & $\mathrm{~A}(\mathrm{~b} \& \mathrm{w})$ & $1: 30,400 / 46$ \\
\hline 18.9 .1992 & 3000 & A (color) & $1: 13,970 / 21$ \\
\hline 18.9 .2002 & 4050 & A (color) & $1: 13,280 / 20$ \\
\hline 21.9 .2006 & 4630 & A (color) & $1: 15,250 / 23$ \\
\hline 8.9 .2009 & 4880 & A (color) & $1: 15,970 / 24$ \\
\hline 28.8 .2012 & 2070 & $\mathrm{D}^{3}$ (RGB,NIR) & $(1: 22,450) / 13$ \\
\hline 28.8 .2015 & 3060 & $\mathrm{D}(\mathrm{RGB}, \mathrm{NIR})$ & $(1: 30,560) / 16$ \\
\hline
\end{tabular}

$1 \ldots$ mean flying height above ground
$2 \ldots$ analog $\quad 3 \ldots$ digital $\quad 4 \ldots$ ground sampling distance

Table 1. Metric aerial surveys 1954-2015

\subsection{Non-metric aerial photographs 2016-2017}

UAV-based aerial surveys were carried out in summer 2016 and 2017 (Table 2). On 26.7.2016 a first UAV overflight of the study area was made using a rotary-wing aircraft (hexacopter twinHEX v.3.0). Although the waypoint flight was disrupted due to still unknown navigation problems of the UAV, most of the study area (C2, cp. Figures 2, 5) could be covered. Because of severe image blur we had to discard 7 photos. 17 photos remained for processing, divided into two disconnected parts, i.e., a western and an eastern one.

\begin{tabular}{|c|c|c|c|c|}
\hline Date & $\begin{array}{l}\text { UAV/ } \\
\text { type }\end{array}$ & Camera & $\begin{array}{l}\text { Number } \\
\text { of photos }\end{array}$ & $\begin{array}{l}\text { GSD } \\
(\mathrm{cm})\end{array}$ \\
\hline 26.7.2016 & $\begin{array}{l}\text { hexacopter } \\
\text { twinHEX } \\
\text { v.3.0/r-w }\end{array}$ & $\begin{array}{l}\text { Ricoh GXR } \\
\text { A12 }\end{array}$ & $\begin{array}{c}13 \text { (west) } \\
4 \text { (east) } \\
\text { waypoint }\end{array}$ & $\begin{array}{l}4.5 \\
4.4\end{array}$ \\
\hline $\begin{array}{c}22.8 .2017 \\
\text { (survey 1) }\end{array}$ & $\begin{array}{c}\text { QuestUAV }{ }^{2} / \\
\text { f-w }\end{array}$ & $\begin{array}{l}\text { Sony ILCE- } \\
6000\end{array}$ & $\begin{array}{c}68 \\
\text { waypoint }\end{array}$ & 5.9 \\
\hline (survey 2) & $\begin{array}{c}\text { DJI }^{3} \\
\text { Phantom 4/ } \\
\text { r-w* }\end{array}$ & $\begin{array}{c}\text { DJI } \\
\text { FC330 }\end{array}$ & $\begin{array}{c}167 \\
\text { waypoint }\end{array}$ & 3.9 \\
\hline (survey 3) & $\begin{array}{l}\mathrm{DJI}^{3} \text { Mavic } \\
\text { Pro/r-w }\end{array}$ & $\begin{array}{c}\text { DJI } \\
\text { FC220 }\end{array}$ & $\begin{array}{c}890 \\
\text { manual }\end{array}$ & 1.6 \\
\hline (survey 4) & $\begin{array}{c}\text { Falcon }^{4} 8 / \\
\text { r-w }\end{array}$ & $\begin{array}{c}\text { Sony } \\
\text { NEX-5N }\end{array}$ & $\begin{array}{c}495 \\
\text { manual }^{\star}\end{array}$ & 1.6 \\
\hline
\end{tabular}

${ }^{4} \ldots$ (ASCTEC, 2018) $+\ldots$ rotary-wing $* \ldots$ fixed-wing $* \ldots$ flight mode

Table 2. UAV-based aerial surveys 2016-2017
On 22.8.2017 we conducted a comparative UAV-based aerial survey using four different UAVs: a fixed-wing UAV (Quest 200 UAV) and three rotary-wing copters, which included two quadcopters (Phantom 4 and Mavic Pro of DJI) and one octocopter (Asctec Falcon 8). Short video films showing selected UAV flights can be downloaded from YouTube (2018). All UAVs of the 2016 and 2017 flight campaigns carried uncalibrated consumer-grade digital cameras (Table 2). All image data were provided in JPEG format. The processing of raw image data was not intended in the present study, especially as not all of the UAVs provided access to raw image data and we wanted no further image data conversion to ease practical work.

\subsection{ALS data 2009}

Additionally, a high-resolution ALS-based DTM with a grid spacing of $1 \mathrm{~m}$ was provided for 2009 by the Regional Government of Tyrol (cp. Figure 2). The original (unfiltered) digital surface model (DSM) was only used in the elevationbased matching process for computing the flow velocity. Small morphological differences between the two models, e.g., missing of erratic rocks, are caused by inherent filtering and remain relatively small.

\subsection{Geodetic measurements 2014-2017}

In 2014 a geodetic monitoring network was set up. It consisted of 4 stable reference points located next to the rock glacier and 14 (moving) observation points on the rock glacier. Measurements have been repeated annually since then using Real-Time Kinematic (RTK) Global Navigation Satellite System (GNSS) technology (related data provided by Kaufmann, 2018a). We used a virtual reference station (VRS) provided by the Austrian Positioning Service (APOS). The accuracies obtained are in the order of $\pm 1.5 \mathrm{~cm}$ in planimetry and $\pm 4 \mathrm{~cm}$ in height as specified in APOS (2018). Measured ETRS89 coordinates were transformed to MGI (Ferro)/Austria GK Central Zone map coordinates using local parameters. In addition, a sufficient number of ground control points (GCPs) and check points (CPs) was temporarily signalized for each annual UAV campaign. This included not only the stable areas in the surroundings of the rock glacier but also the rock glacier itself in order to facilitate precise georeferencing and quality control (Figures 4 and 5, Tables 4 and 5). In 2016 the UAVbased aerial survey was carried out in July and thus did not coincide with the date of the annual geodetic survey.

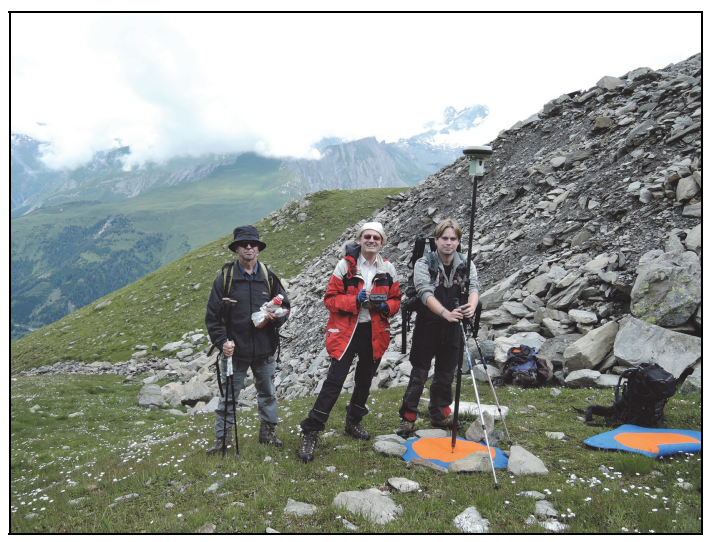

Figure 4. Geodetic measurement (RTK-GNSS) of a GCP close to the frontal slope on 26.7.2016 


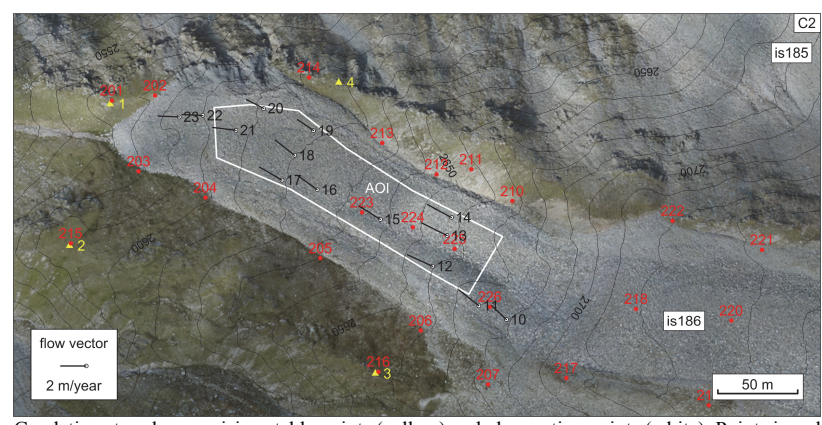

Geodetic network comprising stable points (yellow) and observation points (white). Points in red are temporarily marked GCPs/CPs of the UAV campaign of 22.8.2017. The orthophoto shown dates from this campaign. The white polygon delineates the area of interest (AOI) considered fo computing the mean annual flow velocity as needed in the velocity graph (see Section 6 )

Figure 5. Mean annual horizontal flow vectors for 2016-2017

\section{DATA PROCESSING}

In our study, change detection analysis is based on the intercomparison of multi-temporal DOPs and DTMs. Related research is described extensively in the literature (Bodin et al., 2018; Buchli et al., 2018; Arenson et al., 2016; Bollmann et al., 2015; Kääb, 2005). Practical applications can be found not only in permafrost and rock glacier monitoring, but also in glacier and landslide mapping, where UAV-based studies have recently increased in number (Dall'Asta, 2017; Seier et al., 2017; Turner et al., 2015; Niethammer et al., 2012; Müller et al., 2018).

\subsection{Georeferencing and mapping}

5.1.1 Metric aerial photographs (archive data): All aerial photographs provided by BEV were evaluated using a photogrammetric workstation of Intergraph. The exterior orientation of the image data was either provided by BEV or subsequently determined applying bundle block adjustment using stable natural GCPs selected and measured in the already georeferenced stereomodels. For each epoch (except 2009, where height data were already available) a contemporaneous DTM was generated using dense image matching. We selected $2 \mathrm{~m}$ as a common DTM grid spacing to support DTM differencing. Finally, high-resolution digital orthophotos with a common GSD of $10 \mathrm{~cm}$ were generated (Table 3).

\begin{tabular}{|c|c|c|c|}
\hline Date & $\begin{array}{c}\text { Grid spacing } \\
(\mathrm{m}) \text { of DTM }\end{array}$ & $\begin{array}{c}\text { GSD }(\mathrm{cm}) \\
\text { of DOP }\end{array}$ & Mapping area \\
\hline 24.9 .1954 & 2 & $10^{+}, 20^{+}$ & $\mathrm{C} 1, \mathrm{C} 2$ \\
\hline 29.9 .1969 & $3\left(2^{+}\right)$ & $10^{+}, 20^{+}$ & $\mathrm{C} 1, \mathrm{C} 2$ \\
\hline 6.9 .1974 & 2 & $10^{+}, 20$ & $\mathrm{C} 1, \mathrm{C} 2$ \\
\hline 9.10 .1981 & $3\left(2^{+}\right)$ & $10^{+}, 20^{+}$ & $\mathrm{C} 1, \mathrm{C} 2$ \\
\hline 18.9 .1992 & 2 & $10^{+}, 20$ & $\mathrm{C} 1, \mathrm{C} 2$ \\
\hline 18.9 .2002 & $2.5\left(2^{+}\right)$ & $10^{+}, 20^{+}, 25$ & $\mathrm{C} 1, \mathrm{C} 2$ \\
\hline 21.9 .2006 & $2.5\left(2^{+}\right)$ & $10^{+}, 20^{+}, 25$ & $\mathrm{C} 1, \mathrm{C} 2$ \\
\hline 8.9 .2009 & $1[\mathrm{ALS}$ data], & $10^{+}, 20^{+}, 25$ & $\mathrm{C} 1, \mathrm{C} 2$ \\
\hline 28.8 .2012 & $2.5\left(2^{+}\right)$ & $10^{+}, 20$ & $\mathrm{C} 1, \mathrm{C} 2$ \\
\hline 28.8 .2015 & $2\left(1^{+}\right)$ & $10^{+}, 20$ & $\mathrm{C} 1, \mathrm{C} 2$ \\
\hline 26.7 .2016 & $0.10,1,2$ & $5,10,20$ & $\mathrm{C} 2$ (partial) \\
\hline $22.8 .2017(1)$ & $0.10,1,2$ & $5,10,20$ & $\mathrm{C} 2$ \\
\hline $22.8 .2017(2)$ & $0.10,1,2$ & $5,10,20$ & $\mathrm{C} 2$ (partial) \\
\hline $22.8 .2017(3)$ & $0.10,1,2$ & $5,10,20$ & $\mathrm{C} 2$ (partial) \\
\hline $22.8 .2017(4)$ & $0.10,1,2$ & $5,10,20$ & $\mathrm{C} 2$ (partial) \\
\hline
\end{tabular}

... interpolated value for easier comparison of multi-temporal data
5.1.2 Non-metric aerial photographs (UAV data): The UAV data of 2016 and 2017 were photogrammetrically evaluated using the commercial software Agisoft PhotoScan (Agisoft, 2018). Bundle block adjustment always comprised appropriate camera calibration (F, Cx, Cy, B1, B2, K1-3, P1, P2) and georeferencing using the geodetically measured GCPs. Check points were embedded for quality control. For details see Tables 4 and 5. Finally, digital terrain models with a grid spacing of $10 \mathrm{~cm}$ and digital orthophotos at $5 \mathrm{~cm}$ GSD were computed for all UAV campaigns mentioned (Table 3 ).

The reprojection error computed from image residuals was in the sub-pixel range in almost all UAV-based aerial surveys. Small systematic image errors still remained for almost all cameras (Figure 6). These errors are most probably due to some processing artefacts introduced when converting the RAW image data to JPEG format (Przybilla, 2018). Image corners also show larger image residuals. The rolling shutter option was additionally included in the bundle block adjustment of the QuestUAV image data and improved the accuracy significantly.

For the year 2017 we selected the QuestUAV data (survey 1) for further change detection analysis since it provided highest geometric accuracy and full coverage of the mapping area $\mathrm{C} 2$. See respective digital orthophoto in Figure 5.

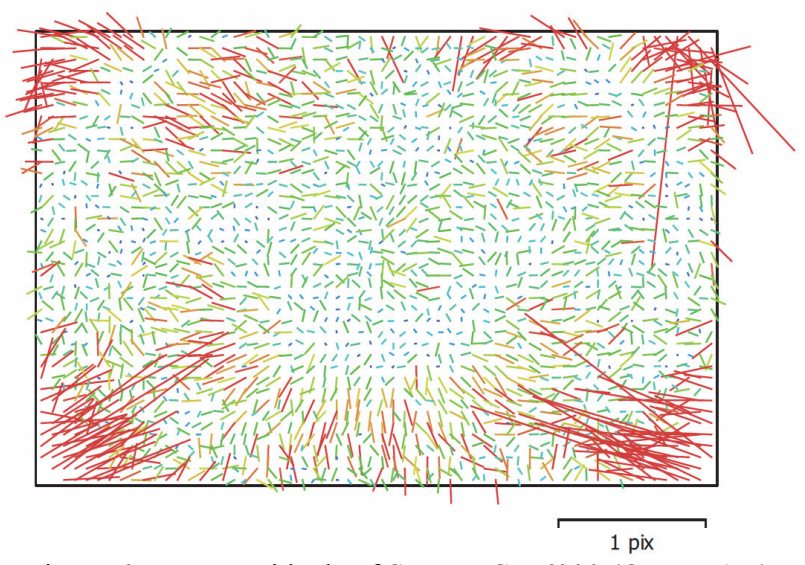

Figure 6. Image residuals of Sony ILCE-6000 (QuestUAV)

\begin{tabular}{|c|c|c|c|c|}
\hline Date & $\begin{array}{l}\mathrm{RMS}_{\mathrm{X}} \\
(\mathrm{cm})\end{array}$ & $\begin{array}{c}\mathrm{RMS}_{\mathrm{Y}} \\
(\mathrm{cm})\end{array}$ & $\begin{array}{l}\mathrm{RMS}_{Z} \\
(\mathrm{~cm})\end{array}$ & $\begin{array}{l}\text { Reprojection } \\
\text { error (pix) }\end{array}$ \\
\hline \multirow{2}{*}{$\begin{array}{c}26.7 .2016 \\
\text { west }\end{array}$} & \multicolumn{3}{|c|}{$11 \mathrm{GCPs}$} & \pm 0.31 (tie pts.) \\
\hline & \pm 2.2 & \pm 1.6 & \pm 7.1 & \pm 0.36 (11 pts.) \\
\hline \multirow{2}{*}{$\begin{array}{c}26.7 .2016 \\
\text { east }\end{array}$} & \multicolumn{3}{|c|}{29 (natural) GCPs } & \pm 0.26 (tie pts.) \\
\hline & \pm 9.3 & \pm 7.7 & \pm 14.0 & \pm 0.51 (29 pts.) \\
\hline \multirow{2}{*}{$\begin{array}{c}22.8 .2017 \\
\text { (1) }\end{array}$} & \multicolumn{3}{|c|}{18 GCPs } & \pm 0.35 (tie pts.) \\
\hline & \pm 1.8 & \pm 1.2 & \pm 2.6 & \pm 0.41 (18 pts.) \\
\hline \multirow{2}{*}{ (2) } & \multicolumn{3}{|c|}{18 GCPs } & \pm 0.47 (tie pts.) \\
\hline & \pm 3.5 & \pm 2.6 & \pm 3.2 & \pm 0.40 (18 pts.) \\
\hline \multirow{2}{*}{ (3) } & \multicolumn{3}{|c|}{12 GCPs } & \pm 1.22 (tie pts.) \\
\hline & \pm 5.9 & \pm 6.2 & \pm 6.4 & \pm 0.85 (12 pts.) \\
\hline \multirow{2}{*}{ (4) } & \multicolumn{3}{|c|}{10 GCPs } & \pm 0.68 (tie pts.) \\
\hline & \pm 1.8 & \pm 1.8 & \pm 1.3 & \pm 0.45 (10 pts.) \\
\hline
\end{tabular}

Table 4. Statistics of the bundle block adjustments (part 1)

Table 3. DTMs and DOPs 1954-2017 


\begin{tabular}{|c|c|c|c|c|}
\hline Date & $\begin{array}{c}\mathrm{RMS}_{\mathrm{X}} \\
(\mathrm{cm})\end{array}$ & $\begin{array}{l}\mathrm{RMS}_{\mathrm{Y}} \\
(\mathrm{cm})\end{array}$ & $\begin{array}{l}\mathrm{RMS}_{\mathrm{Z}} \\
(\mathrm{cm})\end{array}$ & $\begin{array}{c}\text { Reprojection } \\
\text { error (pix) }\end{array}$ \\
\hline \multirow{2}{*}{$\begin{array}{c}\text { 26.7.2016 } \\
\text { west }\end{array}$} & \multicolumn{3}{|c|}{3 check points (CPs) } & \multirow[b]{2}{*}{ \pm 0.24 (3 pts.) } \\
\hline & \pm 1.1 & \pm 2.2 & \pm 6.3 & \\
\hline \multirow{2}{*}{$\begin{array}{c}26.7 .2016 \\
\text { east }\end{array}$} & \multicolumn{3}{|c|}{ no check points } & \multirow{2}{*}{ - } \\
\hline & - & - & - & \\
\hline \multirow{2}{*}{$\begin{array}{c}22.8 .2017 \\
(1)\end{array}$} & \multicolumn{3}{|c|}{6 check points } & \multirow[b]{2}{*}{ \pm 0.41 (6 pts.) } \\
\hline & \pm 1.3 & \pm 0.9 & \pm 1.9 & \\
\hline \multirow{2}{*}{ (2) } & \multicolumn{3}{|c|}{6 check points } & \multirow[b]{2}{*}{ \pm 0.45 (6 pts.) } \\
\hline & \pm 5.4 & \pm 3.4 & \pm 2.2 & \\
\hline \multirow{2}{*}{ (3) } & \multicolumn{3}{|c|}{3 check points } & \multirow[b]{2}{*}{ \pm 0.92 (3 pts.) } \\
\hline & \pm 6.4 & \pm 6.5 & \pm 3.4 & \\
\hline \multirow{2}{*}{ (4) } & \multicolumn{3}{|c|}{4 check points } & \multirow[b]{2}{*}{ \pm 0.48 (4 pts. $)$} \\
\hline & \pm 2.9 & \pm 2.6 & \pm 4.6 & \\
\hline
\end{tabular}

Table 5. Statistics of the bundle block adjustments (part 2)

\subsection{Change detection}

Subsequent deformation analysis included multi-temporal DOPs and DTMs from all photogrammetric epochs 1954-2017. For each time interval (combinations of BEV-BEV, BEV-UAV, UAV-UAV) we computed (1) 2D displacement vector fields using image matching and (2) grids of surface height change by subtracting DTMs. Remaining systematic offsets in planimetry and height were determined in stable areas around the rock glacier and taken into account in the change results. The statistical data obtained also provided information on precision.

5.2.1 Horizontal movement: Horizontal displacement can be retrieved either by tracking (1) surface texture elements of DOPs or (2) surface relief elements of DTMs (Arenson et al., 2016). Method 2 relies on high-resolution DTMs representing characteristic 3D morphology. 2D displacement vectors were computed using an in-house Matlab based toolbox. Area-based image matching works either with bi-temporal digital orthophotos, i.e., 8 bit grayscale images, or bi-temporal digital terrain models, i.e., real numbers height data. We selected the normalized cross-correlation (NCC) coefficient as a measure of similarity. Sub-pixel accuracy was achieved by parabolic fitting. Blunders were detected by back matching strategy and subsequent consistency checks assuming a smooth 2D displacement field. A special option was also to test the displacement/flow direction against slope direction extracted from a synchronized DTM. Remaining blunders were removed by visual inspection. Displacement vectors were computed at regular grid positions, e.g., $5 \mathrm{~m}$ spacing for the $20 \mathrm{~cm}$ DOPs or $2.5 \mathrm{~m}$ spacing for the $10 \mathrm{~cm}$ DOPs. The window size was set to 31 pixels (pix) in most cases. The computation of displacement vectors based on multi-temporal DTMs was only successful for the high-resolution UAV data (10 cm grid spacing) of 2016 and 2017. The matching of the $1 \mathrm{~m}$ grids of 2009 and 2016/17 failed in all areas with strong surface movement/deformation due to inherent dissimilarity of the surfaces and general lack of local prominent surface structures.

For purposes of comparison, all 2D displacement vectors were time scaled to derive mean annual displacement/flow vectors. Subsequently, mean annual flow velocities were interpolated across the entire area to form a continuous velocity field. The precision of the flow velocities obtained was derived from measurements at stable areas in the surroundings of the rock glacier. Accuracy assessment could only be carried out for the data sets 2015, 2016 and 2017 for which additional geodetic measurements were available.

All velocity data, derived from both photogrammetry and geodetic measurements, were compiled to derive a simple velocity graph showing the temporal evolution of the rock glacier's movement 1954-2017. The velocity data refer to an area of interest (AOI) located in the lower half of the rock glacier tongue. The velocity computed is an area average. Geodetic and other sparse velocity data from photogrammetry were appropriately normalized to scale with the given areal extent.

5.2.2 Surface height (volume) change: Surface height change was computed by DTM subtracting/differencing. We selected the ALS-based DTM as a height reference to account for systematic height offsets and to validate single DTM quality. As a result, an indicator for the height accuracy for each DTM was obtained (Table 6). The statistical analysis was restricted to a common stable area $(0.878$ hectares, see Figures 11 and 12) located south of the rock glacier tongue. Horizontal offsets of the DTMs were not considered in this study. Additionally, the accuracy of the UAV-based DTMs was also assessed by means of geodetic measurements. Volume change can be calculated as the areal integral of surface height change over the entire rock glacier area. Since the boundary polygon extracted from the rock glacier inventory does not show the current outline, we digitized a more appropriate one (5.028 hectares, see Figure 11) considering the overall kinematics of the rock glacier and its surroundings. Mass balance is in practice difficult to quantify since the density of the material (mixture of rock and ice) is unknown. Nevertheless, we think that the mean annual surface height change observed is mainly due to ice melt.

\begin{tabular}{|c|c|}
\hline Date & $\begin{array}{c}\text { Height } \text { accuracy }^{+}(\mathrm{m}) \\
\text { of DTM }\end{array}$ \\
\hline 24.9 .1954 & \pm 0.42 \\
\hline 6.9 .1974 & \pm 0.17 \\
\hline 18.9 .1992 & \pm 0.16 \\
\hline 8.9 .2009 & height reference (ALS data) \\
\hline 28.8 .2015 & \pm 0.12 \\
\hline 26.7 .2016 & $\pm 0.09 / \pm 0.09^{*}(30$ points $)$ \\
\hline $22.8 .2017(1)$ & $\pm 0.07 / \pm 0.06^{*}(42$ points $)$ \\
\hline
\end{tabular}

$+\ldots$ standard deviation $(1 \sigma)$

* ... value derived from known geodetic points

Table 6. Height accuracy of DTMs

\section{RESULTS}

\subsection{Horizontal movement}

Velocity data were computed for various time intervals using combinations of BEV-BEV, BEV-UAV, and UAV-UAV image data (Table 7). Table 7 includes both the DOP-based and DTMbased results. In addition to precision, the accuracy of all UAVbased velocity data was assessed by additional geodetic measurements (Table 8). Various thematic maps showing flow vectors or isotachs were produced to visualize flow direction and velocity (cp. Figures 7-9 showing velocity data only). Computer animations (animated GIFs) based on multi-temporal 
DOPs and DTMs can be downloaded from Kaufmann (2018b). These visualizations help to better understand rock glacier movement, especially as surface deformation can be interpreted at different resolution levels, from a general overview to single rocks. The velocity graph 1954-2017 for Tschadinhorn rock glacier is shown in Figure 10. Numerical values can be found in Table 9.

\begin{tabular}{|c|c|c|c|}
\hline Time interval & $\begin{array}{c}\text { Precision }^{+} \\
\text {of velocity } \\
\text { data } \\
\text { (cm/year) }\end{array}$ & $\begin{array}{c}\text { Maximum } \\
\text { flow velocity } \\
\text { (m/year) }\end{array}$ & $\begin{array}{c}\text { Mapping } \\
\text { area }\end{array}$ \\
\hline 1954-1969 & \pm 1.9 & 0.595 & $\mathrm{C} 1$ \\
\hline 1969-1974 & \pm 4.5 & 0.380 & $\mathrm{C} 1$ \\
\hline 1954-1974 & \pm 1.5 & 0.497 & $\mathrm{C} 1$ \\
\hline 1974-1981 & \pm 3.0 & 0.279 & $\mathrm{C} 1$ \\
\hline 1981-1992 & \pm 2.2 & 0.356 & $\mathrm{C} 1$ \\
\hline 1974-1992 & \pm 1.1 & 0.334 & $\mathrm{C} 1$ \\
\hline 1992-2002 & \pm 2.2 & 1.017 & $\mathrm{C} 1$ \\
\hline $2002-2006$ & \pm 2.3 & 1.196 & $\mathrm{C} 1$ \\
\hline 2006-2009 & \pm 2.9 & 1.064 & $\mathrm{C} 1$ \\
\hline 2009-2012 & \pm 3.1 & 1.990 & $\mathrm{C} 1$ \\
\hline $2012-2015$ & \pm 3.2 & 3.533 & $\mathrm{C} 1$ \\
\hline $2015-2016$ & $\begin{array}{l} \pm 6.2 \text { (west) } \\
\pm 12.0 \text { (east) }\end{array}$ & $\begin{array}{l}3.556 \text { (west) } \\
2.829 \text { (east) }\end{array}$ & $\begin{array}{c}\mathrm{C} 2: \\
\text { both parts }\end{array}$ \\
\hline $2016-2017(1)$ & \pm 5.0 (west) & 2.300 (west) & C2: west \\
\hline $2015-2017(1)$ & \pm 3.1 & 2.824 & \\
\hline $2009-2017(1)$ & \pm 0.8 & 2.740 & \\
\hline 2016-2017 (1)* & \pm 10.9 & 2.275 & both parts \\
\hline 2009-2016* & \pm 3.3 & - & few points \\
\hline $2009-2017(1)^{*}$ & \pm 2.6 & - & few points \\
\hline
\end{tabular}

Table 7. Velocity data 1954-2017

\begin{tabular}{|c|c|c|}
\hline Time interval & $\begin{array}{c}\text { Accuracy } \\
\text { velocity } \text { (cm/year) }\end{array}$ & $\begin{array}{c}\text { Number of } \\
\text { geodetic points }\end{array}$ \\
\hline $2015-2016$ & \pm 4.7 & 12 \\
\hline $2015-2017(1)$ & \pm 3.2 & 14 \\
\hline $2016-2017(1)$ & $\pm 5.1 / \pm 2.8^{*}$ & $12 / 13$ \\
\hline & * RMSE $\ldots$ DTM-based flow velocity
\end{tabular}

Table 8. Accuracy of the UAV-based velocity data

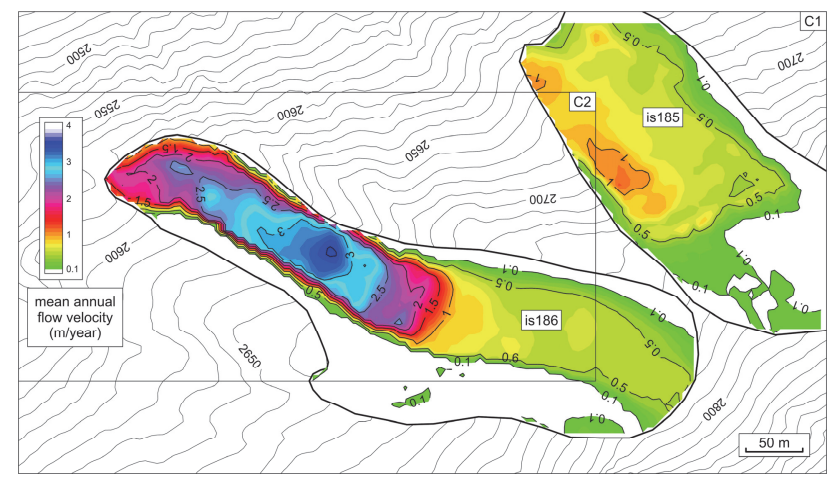

Figure 7. Mean annual horizontal flow velocity 2012-2015

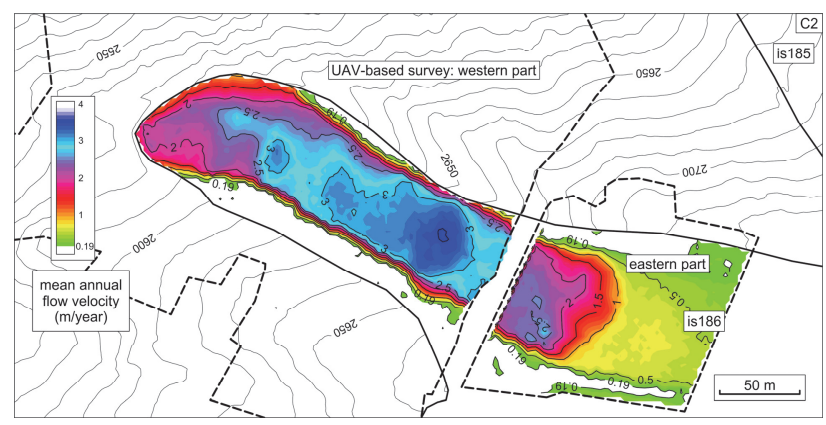

Figure 8. Mean annual horizontal flow velocity 2015-2016

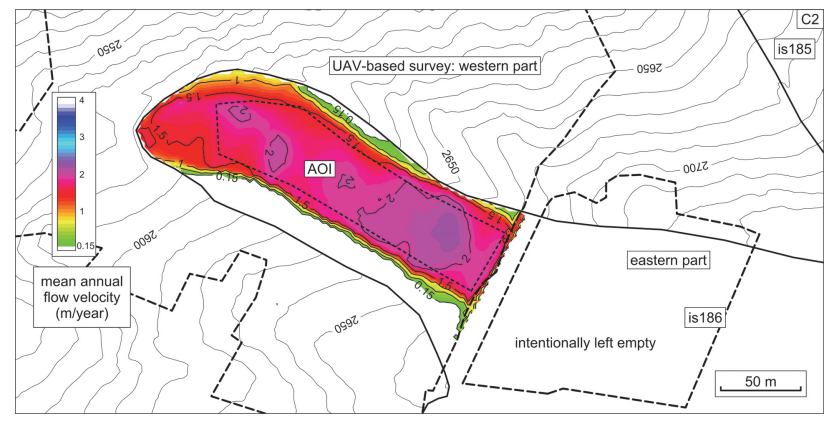

Figure 9. Mean annual horizontal flow velocity 2016-2017

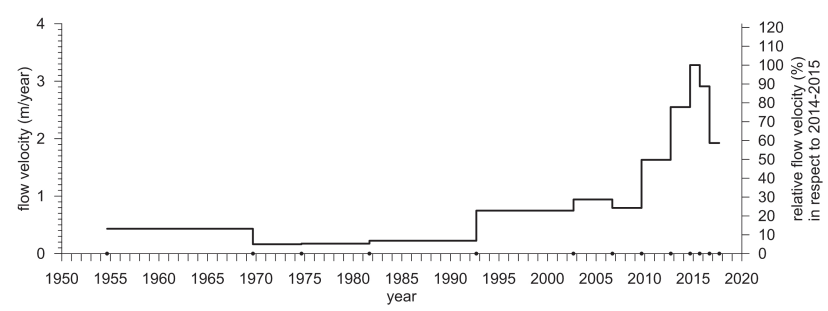

Figure 10. Velocity graph 1954-2017 of Tschadinhorn rock glacier

\begin{tabular}{|c|c|c|}
\hline Time interval & $\begin{array}{c}\text { Mean annual } \\
\text { horizontal flow } \\
\text { velocity }^{+} \text {(m/year) }\end{array}$ & Relative value (\%) \\
\hline $1954-1969$ & 0.433 & 13.18 \\
\hline $1969-1974$ & 0.162 & 4.95 \\
\hline $1974-1981$ & 0.175 & 5.32 \\
\hline $1981-1992$ & 0.224 & 6.83 \\
\hline $1992-2002$ & 0.749 & 22.82 \\
\hline $2002-2006$ & 0.941 & 28.68 \\
\hline $2006-2009$ & 0.794 & 24.20 \\
\hline $2009-2012$ & 1.631 & 49.71 \\
\hline $2012-2014$ & $2.550^{*}$ & 77.72 \\
\hline $2014-2015$ & $3.282^{\#}$ & 100.00 \\
\hline $2015-2016$ & 2.911 & 88.72 \\
\hline $2016-2017$ & 1.925 & 58.65 \\
\hline
\end{tabular}

$+\ldots$ area average (area indicated as AOI in Figures 5 and 9)

* ... derived from velocity data 2012-2015 and 2014-2015

\# ... RTK-GNSS measurements scaled to AOI

Table 9. Numerical values of the velocity graph 


\subsection{Surface height (volume) change}

Surface height change was analyzed for selected time intervals only (Table 10). Furthermore, volume change could only be deduced from those data sets with full coverage of the entire rock glacier, i.e., from the root to the snout. The calculations for the time period 1954-2015 revealed a mean surface height change of $-7.8 \mathrm{~mm} / \mathrm{year}$, which corresponds to a volume change of approx. $-24,000 \mathrm{~m}^{3}$. The time intervals in between also indicate a general loss of volume, with the exception of the time period 2009-2015, in which no significant volume change was observed.

The available UAV data did not allow volume change to be accurately quantified since coverage was incomplete (cp. Figures 11 and 12).

\begin{tabular}{|c|c|c|c|}
\hline Time interval & Min. $(\mathrm{m})$ & Max. $(\mathrm{m})$ & $\begin{array}{c}\text { Mean surface height } \\
\text { change }^{+}(\mathrm{mm} / \text { year })\end{array}$ \\
\hline $1954-1974$ & -2.34 & 4.43 & $-3.9 \pm 0.45^{*}$ \\
\hline $1974-1992$ & -5.73 & 2.52 & $-9.8 \pm 0.23^{*}$ \\
\hline $1992-2009$ & -4.59 & 6.66 & $-13.4 \pm 0.20^{*}$ \\
\hline $2009-2015$ & -2.99 & 6.05 & $0.8 \pm 0.41^{*}$ \\
\hline $1954-2015$ & -6.19 & 11.84 & $-7.8 \pm 0.14^{*}$ \\
\hline $1954-2017$ & -7.43 & 12.62 & $(-4.4) \pm 0.14^{*}$ \\
\hline
\end{tabular}

... aggregated mean over the entire rock glacier area (see Figure 11)

* ... standard deviation estimated from stable area (2197 sample points, see Figure 11)

Table 10. Surface height change

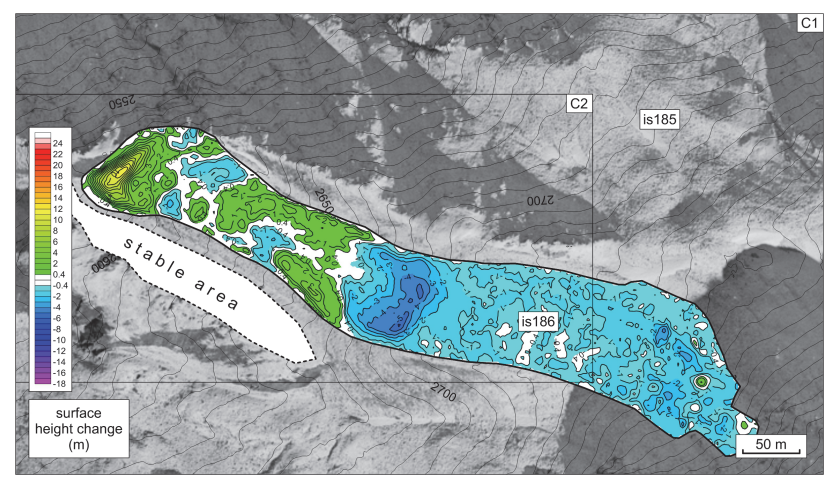

Figure 11. Surface height change 1954-2015

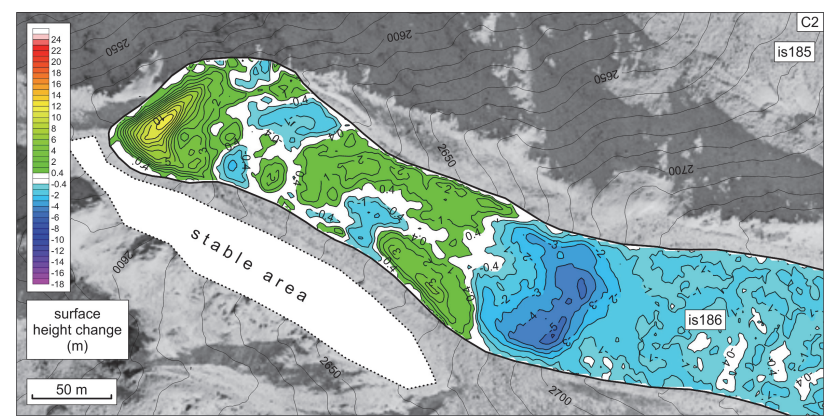

Figure 12. Surface height change 1954-2017

\section{DISCUSSION AND OUTLOOK}

The velocity graph obtained clearly shows changing movement rates over time: a maximum mean annual flow velocity of 3.282 $\mathrm{m} /$ year (geodetically measured) was reached in 2014-2015; a minimum value of $0.162 \mathrm{~m} /$ year (only $5 \%$ of the maximum value) was calculated for the time period 1969-1974. The time period 1954-2009 was a period of generally little movement, whereas from 2009 onwards the flow velocities increased significantly. Volume change at Tschadinhorn rock glacier due to ice melt (permafrost degradation) is relatively small. For example, mean surface height change for the time period 19542015 amounts to $-7.8 \mathrm{~mm} /$ year. Unfortunately, our UAV data are incomplete in respect to full coverage of the entire rock glacier area. Volume change derived from UAV data can thus only be assessed in a more qualitative way.

The investigations presented in this paper have shown that UAV-based aerial surveys can fully replace manned aerial surveys (as carried out by BEV) for rock glacier monitoring given that (1) the UAV-based surveys are properly executed (high image overlap, good image quality, appropriate GSD, stable camera geometry, sufficient and accurate ground control) and also provided that (2) the monitoring/rock glacier area is limited in size and not too remote for convenient access. UAVbased fieldwork is intentionally restricted to one-day operations for reasons of cost efficiency. Furthermore, computer generated time-lapse animations (GIF format) using multi-temporal orthophotos or shaded reliefs greatly help to visualize any spatio-temporal surface change. Also in this respect UAV-based results benefit from the generally higher spatial resolution as compared to the governmental data provided by BEV.

BEV has already announced a new aerial survey for 2018. The authors of this paper plan to carry out a coincident UAV-based aerial survey, possibly with full coverage of the whole rock glacier area.

We intend to change over to RTK/PPK GNSS enabled UAVs in the near future in order to avoid strenuous deployment and measurement of (too many) ground control points.

\section{ACKNOWLEDGEMENTS}

The authors gratefully acknowledge support from NAWI Graz. Furthermore, this work was supported by Hohe Tauern National Park Carinthia and OeAV-Patenschaftsfonds Nationalpark Hohe Tauern. The help of Alexander Kleb, Kevin Roth, Carlo Augello, Wolfgang and Hildegard Seka in the 2016 and 2017 field campaigns is kindly appreciated. Aerial photographs (1954-2015) and ALS data (2009) were provided by BEV and TIRIS, Land Tirol.

\section{REFERENCES}

Agisoft, 2018. http://www.agisoft.com/ (18 June 2018)

APOS, 2018. http://www.bev.gv.at/ (18 June 2018)

Arenson, L.U., Kääb, A. and O'Sullivan, A., 2016. Detection and Analysis of Ground Deformation in Permafrost Environments. In: Permafrost and Periglacial Processes, 27 (4), pp. 339-351. doi:10.1002/ppp.1932 
ASCTEC, 2018. http://www.asctec.de/asctec-professional-uav/ (18 June 2018)

Barsch, D., 1996. Rockglaciers: indicators for the present and former geoecology in high mountain environments. Springer Series in Physical Environment, 16, Springer, 331 p.

Bodin, X., Thibert, E., Sanchez, O., Rabatel, A. and Jaillet, S., 2018. Multi-Annual Kinematics of an Active Rock Glacier Quantified from Very High-Resolution DEMs: An ApplicationCase in the French Alps. In: Remote Sensing, 10(4), 547. doi: $10.3380 /$ rs 10040547

Bollmann, E., Girstmair, A. Mitterer, S., Krainer, K., Sailer, R. and Stötter, J., 2015. A Rock Glacier Activity Index Based on Rock Glacier Thickness Changes and Displacement Rates Derived From Airborne Laser Scanning. In: Permafrost and Periglacial Processes, 26 (4), 347-359. doi:10.1002/ppp.1852

Buchenauer, H.W., 1990. Gletscher- und Blockgletschergeschichte der westlichen Schobergruppe (Osttirol). Marburger Geographische Schriften, Heft 117, Philipps-Universität Marburg, in German, 206 ff.

Buchli, T., Kos, A., Limpach, P., Merz, K., Zhou, X., 2018. Kinematic investigations on the Furggwanghorn Rock Glacier, Switzerland. In: Permafrost and Periglacial Processes, 29 (1), 3-20. doi:10.1002/ppp.1968

Dall'Asta, E., Forlani, G., Roncella, R., Sanntise, M., Diotri, F. and Morra di Cella, U., 2017. Unmanned Aerial Systems and DSM matching for rock glacier monitoring. In: ISPRS Journal of Photogrammetry and Remote Sensing, 127, pp. 102-114. doi:10.1016/j.isprsjprs.2016.10.003

DJI, 2018. https://www.dji.com/de (18 June 2018)

Filwarny, J.O. and Wisiol, K., 2012. Quantifizierung der Oberflächendeformation von aktiven Blockgletschern in Osttirol durch photogrammetrische Zeitreihenanalyse, Bachelor Thesis, unpublished, in German, Institute of Geodesy, TU Graz, $49 \mathrm{p}$.

Fischer, A. et al., 2015. The Austrian Glacier Inventories GI 1 (1969), GI 2 (1998), GI 3 (2006), and GI LIA in ArcGIS (shapefile) format. https://doi.org/10.1594/PANGAEA.844988

Kaufmann, V., 2010. Measurement of surface flow velocity of active rock glaciers using orthophotos of virtual globes. In: Geographia Technica, Special Issue, 2010, Cluj University Press, pp.68-61.

Kaufmann, V., 2012. Detection and quantification of rock glacier creep using high-resolution orthoimages of virtual globes. In: International Archives of the Photogrammetry, Remote Sensing and Spatial Information Sciences, Melbourne, Australia, Vol. XXXIX-B5, pp. 517-522.

Kaufmann, V., 2017. Tschadinhorn Blockgletscher, Schobergruppe, Hohe Tauern - ein Beitrag zur aktuellen Kinematik. In: Lienhart, W. (ed.), Ingenieurvermessung 17, Beiträge zum 18. Ingenieurvermessungskurs Graz, 2017, in German, Wichmann Verlag, Berlin/Offenbach, pp. 427-438.
Kaufmann, V. 2018a.

https://www.staff.tugraz.at/viktor.kaufmann/Tschadinhorn_Roc k_Glacier/ (18 June 2018)

Kaufmann, V. 2018b.

https://www.staff.tugraz.at/viktor.kaufmann/animations.html\#T schadinhorn_rock_glacier (18 June 2018)

Kaufmann, V. and Kellerer-Pirklbauer, A., 2015. Regional quantification of rock glacier movement in Austria using governmental GIS data. Geomorphometry.org/2015, http://geomorphometry.org/system/files/KaufmannKellerer2015 geomorphometry.pdf (18 June 2018)

Kääb, A., 2005. Remote Sensing of Mountain Glaciers and Permafrost Creep. Schriftenreihe Physische Geographie, Glaziologie und Geomorphodynamik, 48, Geographisches Institut, Universität Zürich, 264 p. http://folk.uio.no/kaeaeb/publications/habil_screen.pdf (28 June 2018)

Kellerer-Pirklbauer, A., Lieb, G.K. and Kleinferchner, H., 2012. A new rock glacier inventory of the eastern European Alps. In: Austrian Journal of Earth Sciences, 105(2), pp. 78-93.

Mikl, T., 2015. Quantifizierung und Visualisierung der raumzeitlichen Veränderungen von ausgewählten Blockgletschern in der Schobergruppe, Hohe Tauern, Bachelor Thesis, unpublished, in German, Institute of Geodesy, TU Graz, $44 \mathrm{p}$.

Niethammer, U., James, M.R., Rothmund, S., Travelletti, J. and Joswig, M., 2012. UAV-based remote sensing of the SuperSauze landslide: Evaluation and results. In: Engineering Geology, 128, pp. 2-11. doi.org/10.1016/j.enggeo.2011.03.012

Przybilla, H-J, 2018. Untersuchungen und erste Ergebnisse zur geometrischen Qualität marktgängiger Kameras für den UAVEinsatz. In: allgemeine vermessungs-nachrichten (avn), 125(12), pp. 13-21.

QuestUAV, 2018. https://www.questuav.com/drones/ (18 June 2018)

Seier, G., Kellerer-Pirklbauer, A., Wecht, M., Hirschmann, S., Kaufmann, V., Lieb G.K. and Sulzer, W., 2017. UAS-Based Change Detection of the Glacial and Proglacial Transition Zone at Pasterze Glacier, Austria. In: Remote Sensing, 9(6), 549. doi:10.3390/rs9060549

Turner, D., Lucieer, A. and de Jong, S.M., 2015. Time Series Analysis of Landslide Dynamics Using an Unmanned Aerial Vehicle (UAV). In: Remote Sensing, 7(2), pp. 1736-1757. doi:10.3390/rs70201736

twinHEX, 2018. https://start.twins.co.at/ (18 June 2018)

YouTube, 2018.

https://www.youtube.com/channel/UCME9xzw_O4FST8YmQ E3QKkA (28 June 2018)

Müller, J., Vieli, A. and Gärtner-Roer, I., 2018. Accuracy assessment and application of UAV-derived digital elevation models in a high mountain environment. Conference Programme \& Book of Abstracts, 6 ${ }^{\text {th }}$ Int. Conf. on "Small Unmanned Aerial Systems for Environmental Research", June 27-29, 2018, Split, Croatia, pp. 63-64. 